\title{
White Fear and US Racism in the Era of Obama: The Relevance of Neoliberalism
}

\author{
Luigi Esposito ${ }^{\mathrm{i}}$
}

Despite having more access to wealth and political influence than other groups, many White Americans perceive themselvesperhaps more than ever-as victims of political correctness and state sponsored reverse discrimination. In light of these concerns, I make three general points in this article. First, I argue that the presumed shift away from neoliberalism by Obama's "big government" has spurred an anti-statist backlash in the US that draws from, and reinforces, the myth of white victimhood. Second, I address how neoliberalism and post-racialism (which Obama embraces) are mutually supportive ideologies that sustain the racial status quo. Lastly, I suggest that challenging contemporary structures of racial inequity requires anti-racist measures that break completely from the neoliberal/post-racial paradigm. [Article copies available for a fee from The Transformative Studies Institute. E-mail address: journal@transformativestudies.org Website: http://www.transformativestudies.org (C2011 by The Transformative Studies Institute. All rights reserved.]

KEYWORDS: Neoliberalism, Post-Racialism, Color-Blindness, Obama, Tea Party Racism, Anti-Racism.

\footnotetext{
${ }^{\text {i }}$ Luigi Esposito, Ph.D., is Associate Professor of Sociology and Criminology at Barry University in Miami Shores, FL. He has published numerous articles on issues related to race and ethnic relations, social theory, globalization, and ethics. His research has appeared in various professional journals, including The Sociological Quarterly, The Western Journal of Black Studies, Journal of Aging and Identity, Studies in Symbolic Interaction, and Perspectives on Global Development and Technology. He is co-editor (with Vicente Berdayes and John W. Murphy) of The Body in Human Inquiry: Interdisciplinary Explorations of Embodiment. (Cresskill, NJ: Hampton Press. 2004); and is co-editor (with Laura Finley) of the upcoming book titled Grading the 44th President: A Report Card on Barack Obama's First Term as a Progressive Leader, published by Praeger. Address correspondence to: Luigi Esposito, e-mail: Lesposito@mail.barry.edu; Tel: $305-899-4879$.
} 